\title{
TRENDS IN THE ETHNIC HISTORY DEVELOPMENT OF THE LOWER DON POPULATION AND THEIR REFLECTION IN MODERN ETHNO-CULTURAL BRANDS OF THE ROSTOV REGION
}

\author{
Segey V. Chernitsyn, Natalya V. Shishova \\ Don state technical university. Rostov-on-Don, Russian Federation \\ science-almanac@mail.ru
}

The territory of the Lower Don developed as a polyethnic region, for the history of which migration, inter-ethnic contacts, the interaction of different cultures, the formation of mixed ethnic and anthropological groups were characterized. The ethnic development from the middle ages have been affected by the struggle of the Eastern Europe countries and the Middle East for control of the territory. Around the turn of the $\mathrm{XV}-\mathrm{XVI}$ centuries a new stage of ethnic history that continues up to the beginning of the XX century begins and it is characterized by the occurrence of the region into Russia, a gradual predominance of the East Slavic population, changing cultural landscape of the territory, formation of new system of socio-economic relations. The main factor of development in this phase was the don Cossacks. The beginning of XX c. can be considered as a boundary in the evolutionary ethnic development of the region, after which political and socio-cultural transformations related to the Soviet stage of Russian history began. By this time, ethnic communities were formed on the Don, which at the present time form the basis of the Rostov Region multinational population. Some ethno-cultural realities, preserved to the present day, have turned into symbols of the territory, ethno-cultural brands, the main of which is the Don Cossacks.

Key words: ethnic history, the Lower Don (the Don region-Priazovie), ethnocultural brand, multi-ethnic composition of the population, the Don Cossacks.

[Черницын С.В., Шишова Н.В. Тенденции развития этнической истории населения Нижнего Дона и их отражение в современных этнокультурных брендах Ростовской области]

Территория Нижнего Дона развивалась как полиэтнический регион, для истории которого были характерны миграции, межэтнические контакты, взаимодействие различных культур, формирование смешанных этнических и антропологических групп населения. На этническое развитие, начиная с эпохи средневековья, влияла борьба государств Восточной Европы и Ближнего Востока за контроль над этой территорией. Примерно с рубежа XV-XVI в. начинается новый этап этнической истории, который продолжается до начала XX в. и характеризуется вхождением региона в состав России, постепенным преобладанием восточнославянского населения, изменением культурного ландшафта территории, формированием новой системы социально-экономических отношений. Определяющим фактором развития на этом этапе стало донское казачество. Начало XX в. можно рассматривать как рубеж в эволюционном этническом развитии региона, после которого начались политические и социокультурные трансформации, связанные с советским этапом отечественной истории. К этому периоду на Дону сформировались этнические общности, которые в настоящее время составляют основу многонационального населения Ростовской области. Некоторые этнокультурные реалии, сохранившись до наших дней, превратились в символы территории, этнокультурные бренды, основным из которых является донское казачество.

Ключевые слова: этническая история, Нижний Дон (Подонье-Приазовье), этнокультурный бренд, полиэтнический состав населения, донское казачество.

Segey V. Chernitsyn - candidate of history, associate professor. Don state technical university. Rostov-onDon, Russian Federation.

Natalya V. Shishova - candidate of history, associate professor. Don state technical university. Rostov-onDon, Russian Federation.

Черницын Сергей Вячеславович - кандидат исторических наук, доцент. Донской государственный технический университет. г. Ростов-на-Дону, Россия. 
Шишова Наталья Васильевна - кандидат исторических наук, доцент. Донской государственный технический университет. г. Ростов-на-Дону, Россия.

The study of ethnic history issues, especially such macroregions, as the North Caucasus and wider - the South of Russia, is of scientific and practical interest, which explains the emergence of scientific research, mainly devoted to the North Caucasus. At the same time, similar problems in the history of the Lower Don (the Don Region-Priazovie) have not been adequately studied. In the present work, it is supposed to characterize the trends in the ethnocultural development of the given region in the period from the 17th to the early 20th century and to show the reflection of these processes in the system of ethnic symbols (brands).

The historically developed region - the Lower Don (Podonie-Priazovie), the territory of which has been predominantly occupied by the Rostov region since 1937, is considered in the regional literature as a part (microregion, subregion) of the South of Russia and correlated with the North Caucasus [7, p.141]. Such construction is justified for the modern realities, connected with the political and socio-economic development of the end of XIX XX centuries. Geographically and ethnographically, not being a part of the North Caucasus, the Rostov Region (the Don region and Priazovie), taking into account economic, ethno-demographic and administrative-political changes in the 20th century, is currently regarded as a kind of this region center. It should be noted that the part of Volgograd region territory (until 1961 - Stalingrad) formed on December 5, 1936, also belongs to the Lower Don (Podonie).

However, in the past, up to last. quat. XIX century, especially in ancient times and the Middle Ages, the Lower Don (Don region-Priazovie) was ethnographically and culturally more connected with the territories of the Lower Volga region-the Urals and the southwestern Black Sea region (southern regions of modern Ukraine). They were united by a single landscape space - the Pontic-Caspian steppe (Polovtsian steppe, Wild Field), which was the western part of the Eurasian ecoregion (Eurasian, Great Steppe), extending from the lower Danube to the Pacific ocean. Part of this landscape was also the steppe Ciscaucasia, which population, unlike the piedmont and mountain regions of the Caucasus, at all times had connections with Podonie. A number of scientists (L.N. Gumilev, E.N. Chernykh) pay attention to the historical and cultural significance of this single steppe space in the development of Eurasia [11].

Such natural factor as the presence of the Don River and the smaller rivers flowing into it (North Donets, Sal, Manych, and etc.) played an important role in the formation of the Lower Don region within the boundaries of the present Rostov and parts of the Volgograd region. A single hydraulic system crossing the territory from the north to the south "united" it, creating the prerequisites for the resettlement and adaptation of representatives of agricultural cultures, including the predecessors of the Don Cossacks.

The territory of the Lower Don has long been a contact zone. Judging by the archaeological monuments, already from III millennium BC. e. tribal groups that traveled from the east (the North Caucasus and the Volga-Urals) to the west collided and interacted here; and also from the north (the forest-steppe zone of the European part of Russia) to the south. The multi-ethnic, and later - multi-ethnic composition of the population was objectively promoted:

1. The geographic location of the region is at the junction of Europe and Asia: its location is in the steppe zone, stretching from the Pacific to the north of the Balkan Peninsula.

2. Favorable natural and climatic conditions, rich fauna and flora, which attract migrants and facilitate their adaptation. 
3. Absence of serious geographical barriers (mountain systems, deserts) that could impede the relocations and contacts of various groups. The river Don was not such a natural obstacle and was rather a connecting artery.

4. The presence of a single hydraulic system, consisting of Don river and the rivers flowing into it with their inflows.

Already archaeological monuments of the Bronze Age reflect the interaction of different cultures and their interpenetration in the region under investigation. Here the tribes of Cimmerians, Scythians, Sarmatians were successively replaced at the end of the 1st millennium BC. At the same time, the ancestors of modern Adyghe people-meot [11, p.7-8] lived on the territory of the Azov Sea.

The Greek colonization of the Northern Black Sea Region, begun in the 7th century $\mathrm{BC}$. is the part of the large-scale settlement of the Hellenes along the shores of the Mediterranean and Black Seas. On the territory of the Don, ancient cities arose due to the eastern direction of this colonization (the banks of the Kerch Strait, the Black Sea coast of the Caucasus, the Azov Sea). Kremn (near Taganrog) and Tanais were within the modern Rostov region, with which their factories were connected [5, p.84-85]. According to D.B. Shelov, civilization, combining features of antique culture and local tribes culture (Scythians, Sarmatians, Meotes) was formed in the Black Sea region (including Azov sea region). Exploring Tanais, he singled out a special subculture of the ancient Tanaites as a result of intercultural contacts) [12], [13].

The period from the 1st millennium AD was characterized by further political and ethno-cultural changes. Iranian-speaking Alans, German-speaking Goths, Turkic-speaking Huns, and north, in the forest-steppe zone and not the Upper Don, Slavs appeared in the Black sea steppes. From YI to the beginning. XIII centuries nomadic Turkic tribes: Bulgars, Khazars, Pechenegs, Torques, Polovtsians politically dominated here with breaks. Settlements of the Eastern Slavs appeared on the Lower Don (i.e. - in the territory of the present Rostov region) since IX century [3, p.39-40]. The Slavic-Russian population was represented by the inhabitants of the principality with the center in the town of Belaya Vezha (modern Tsimlyansky district) that existed before the Polovtsians arrival in the eleventh century and by the brodniks-militarized communities in which some historians tend to see the predecessors of the Don Cossacks. And after Mongols coming to the Don steppes the Russian people settlements, admitted the nomads power, preserve there.

The Golden Horde, which politically united the region, dominated in XIII-XVI c. in the Lower Don (Podonie-Priazovie) after the disintegration of which the nomad camps (Big Horde, the Astrakhan and, especially- Crimean khanate) tried to control the territory. Considering the role of the cities in the region formation, it is noteworthy that since XI c. such centre was Azak (Azov in the Turkish period), which had the large household and military significance. Representatives of different people, including Slavic Christians settled here, especially in the Golden Horde times. It is also known that Adyghes (Circassians) lived on the territory of the Azov Sea in the beginning of XYc. Turkey is established since XV c. in the Black sea region. In 1471, the Turks seized the Azov (former Azak), which for decades turned into a stronghold of the Ottoman rule on the Don and in the Kuban Territory. The Crimean Khanate, which in 1478 became the vassal of the Ottoman state, really controlled only the mouth of the Don and the northern coast of the Azov Sea. This is different from the situation in neighboring regions, where the Khanate (and hence Turkey) owned the territories of the southern, Black Sea regions of modern Ukraine, the western Kuban, the Black Sea coast of the Caucasus.

In the ethnic history of the region, one should mention the presence of Italians in the XIII - early XIV c. which appeared to be the result of their active colonial expansion. According to the researchers (V.L. Egorov, P.A. Larenok) at the end of XIII c. 39 colonies, including those situated along the coast of the Azov Sea (Matrega, Mapa, Porto Pisano, 
etc.), appeared. They belonged to the Genoeses and the Venetians, but also included the Pisa trading stations. Tana, located on the site of modern Azov was the most northern colony. In the middle of XVc. the Italian colonies stopped their existence in connection with campaigns of Tamerlan to Don, Adyghes incursions and - Black Sea region conquest by Turkey [6, p.108-109].

In the XV - XVI c. there was a consolidation of the groups of the Turkic-speaking population into larger ones - the Tatar and Nogai communities, designated in the sources by the common ethnicon name "Tatars", at the same time an unexplored group of Azov Turks formed in the south of the region. Disappearance (or - a significant reduction) of the Adyghe and Greek population in the Azov Sea was one of the ethnic tendencies development. In fact, the northern Azov Sea, the territory associated with the Turkish Azov was the more populated place. The main part of the Don lands in the sources of the XV-XVII centuries was described as "Wild Field", for Russians - an unknown and dangerous zone, which was controlled by Turkic-speaking nomads. Paramilitary Cossack groups, whose appearance can be regarded as the beginning of a new Cossack, and if you look more broadly - the Russian stage in the ethnic history of the region were formed and settled on the Don in this unfavorable ethno-political environment.

The question about Don Cossacks history origin is still controversial. Therefore, we focus on the XVI c., since at the time the existence of Cossack communities is obvious, finds confirmation in a number of sources (references about the towns of Sary-Azman in 1549, the emergence of Cherkassy town in 1570 and 1593 and other).

This stage of ethnic history is associated with the development of the Cossacks and the gradual integration of the region into Russia. Chronologically it covers a segment since the end of XYI before the beginning of XX centuries. The land of the Don Cossacks occupied a large part of the modern Rostov region, having turned to the end of the XIII century into the internal territory of the Russian Empire. And the military-political formation - the Don Army, firmly established in the region as early as the XVII century.

Political changes of the XVIII-1 st half of the XIX c. were characterized by the loss of the Don Army autonomy and the gradual transformation of the Cossacks into the military class. In the mentioned period, there is also an increase in the number of East Slavic (especially not Cossack) population, economic development of steppe regions takes place, property and social stratification is growing. This is the beginning of a Russian, qualitatively new stage in the ethnic history of the region.

Changes in ethnic composition take place in the conditions of significant socioeconomic and political shifts. Back in the XYII century. the number and political role of the Turkic-speaking population was great: the Nogais (who make up the majority), the Crimean Tatars, and the Turks in the Azov Sea. Kuban Adyghes (Circassians) coming with the war against the Cossacks are often mentioned. Kalmyks, which will later become one of the ethnic components of the Don Cossacks appear on the Don in the 1630's [15].

But at the same time the East Slavic Russian population is growing steadily. This trend continues in the XYIII century. and according to Professor A.P. Pronshtein, by the end of the century the number of Russians and Little Russians (Ukrainians) exceeded 200 thousand people [8, p.11]. The processes leading to a quantitative and political predominance of the East Slavic population, that was accompanied by changes in the cultural landscape, become irreversible. This also makes it possible to single out a separate Russian stage in the ethnic history of the region. The number of Don Cossacks during this period is growing as due to migration and demographic factors, so due to the birth rate increase. A layer of non-Cossack Russian and Ukrainian population is formed simultaneously with the Cossacks, and migration from the territory of modern Ukraine (Little Russia) was inferior only to Great Russia from the territory of Russia [8, p.44-70], [10, p. 438-439]. The Don Cossacks was the main factor of the military-political, economic and cultural development 
of the Lower Don- Priazovie and acted as the most status-based group of the population. In connection with the economic development of the Don Territory, new lands were developed, peasant and non-Cossack settlements were established, many of which became the basis for modern settlements in the Rostov Region. A great role in the political, social and ethnic development of the (Lower Don-Priazovie) Don region was played by the fortresses, which eventually became cities, in the first place - Taganrog and St. Demetrius of Rostov, the future Taganrog and Rostov-on-Don [14, p.16-23]. Azov, conquered from the Turks, by the end of the XVIII century, had lost its former significance.

There is a decrease in the share of Crimean Tatars, Turks, and Nogais in the total population. But the layer of Greeks, Georgians and especially Armenians grows [4, p.107109]. The rows of Cossacks, mainly in the lower Don, along with the representatives of Turkic-speaking people, Kalmyks and Highlanders, are replenished by Greeks, Georgians, Poles. For the settlement of the Lower Don and the Azov Sea, which constitute the territory of the modern Rostov region, for 3 centuries, since the XVIII century, the following indice were characteristic:

1. High growth rates.

2. Ethnic and social heterogeneity, but Russian and Ukrainian population prevailed already from the 2nd part of XVIII c.

3. High migration activity is as a factor of demographic growth and, as a result, there is a large role of migrations in demographic growth.

Although these processes continue, but in the XIX - beginning of XX centuries one can distinguish the following features: the natural mechanisms prevalence of demographic growth, associated with the spread of families and fertility; and also - the development of urbanization processes, especially after the entry into the Don Army the cities of Taganrog, Rostov, Nakhichevan in 1887.

According to the All-Russian Population Census of 1897, more than 2 million people lived on the territory of the Don Military Region, from which up to 95\% were Orthodox. And up to $40 \%$ of this number were Don Cossacks [9, p. 234-235]. Don Kalmyks, who were part of the Cossack class, but retained domestic and religious characteristics lived in the south-east of the region, on the territory of the present-day Salsk, Proletarian and repair districts [15].

The population of the Don Military Region southern districts, especially in the cities of Rostov-on-Don and Taganrog was the most heterogeneous in ethnical relation. There are quite a few layers of Armenians (especially in Nakhichevan), Greeks (especially in Taganrog), Jews (Rostov-on-Don) were formed, and representatives of other people of Russia and even foreigners also lived there. Crimean Tatars and Turks lived around Taganrog and in the city.

German colonies are rapidly spreading also in the south of the region from the end of the XIX century. The total number of Germans on the Don to the end. XIX c. was up to 10 thous. people, and in the North Caucasus (without the Don Cossack Region) - 39.5 thous. But the growth rate of this group was high, according to the census of 1897, the number of Germans in the North Caucasus region, compared with 1876, increased by 7.5 times [2, p.43-44.]. The polyethnic nature of the population should not be exaggerated. Rostov historian S.A. Shpagin, having examined the materials of the All-Russia Population Census of 1897, believes that with all the diversity "a fairly rigid structure connected with ethnic history" was characteristic for Don. On the east, the East Slavic, predominantly Russian (Great Russians), the Orthodox population prevailed. Cossacks, remaining a highly status group, were already inferior in numbers to peasants: 1,026 thousand of people - Cossacks and 1222621 - peasants. The most numerous groups were: Russians (Great Russians) 1712898 thousand; Ukrainians (Little Russians) - 719655 thousand; Kalmyks (mostly Cossacks) - 32,283 thousand; Armenians - 27239 thousand of people. The Belarusians, 
Poles, Greeks, etc., whose numbers ranged from 9,000 (Byelorussians) to 2-3 thousand (Poles, Greeks, Jews, Tatars, etc.) or even - several hundred of people, came next [16, cp. 15-17], [9, p.234-235].

We examined the general characteristics of ethno-cultural changes in the studied region population from antiquity to the beginning of $X X \mathrm{c}$. The beginning of this century is a milestone in the evolutionary ethnic development of the region, to which the main ethnic communities, living on the territory of the Don Cossack Region came as formed ethnic groups or their local groups (intra-ethnic entities).

Revolutionary turmoils of the $1^{\text {st }}$ quarter of $X X$ c. can be regarded as the beginning of Soviet stage in ethnical history of Russian people, including - the former region Don troops, deserving the separate studying. There have been major changes in the sociopolitical and ethno-cultural nature in the course of Soviet construction. Moreover, the ethnic palette of the already modern Rostov region was changed. However, the most modern ethnic groups, primarily - Russians, Armenians, Ukrainians, and Greeks live on the Don land since the pre-revolutionary times. And the Don Cossacks, having preserved their selfconsciousness and some traditions, entered the 1990s. in the period of political and ethnocultural activity [9, p.236-238].

The modern ethno-cultural brands of the Don also ascend to the pre-revolutionary period. The first of them is the idea of the polyethnicity (multinationality) of the Don region, which is reproduced both at the regional level (multinational Don), so at the level of cities (multinational Rostov, Taganrog) and individual districts. This is a positive political brand, convenient for the of an attractive image formation of the Rostov region.

The historical and cultural heritage is an integral and very important part of the common cultural potential for the region, but the "contribution" of different ethnoses to it is not the same. Of course, the question is not about the unequality of ethnic groups and their cultures, but only about the fact that they are represented in various degrees in the historical past. As a consequence, their cultures are differently reflected in the heritage of this past. In our opinion, the status of ethno-cultures in the structure of historical and cultural heritage is determined by: the modern number and social status of the ethnic community; its role and status in the historical past of the region; the presence of memory places and the preservation of the material and artifact environment of this culture; state of socio-cultural mechanisms of its reproduction.

Noting the historical equivalence of peoples, it should be recognized that the cultures of only certain ethnic communities (ethnoses) are perceived as unique symbols of the regions. The Don Cossacks is appeared to be such symbol with regard to the Rostov region territory. In the mass consciousness there is a stable stereotype: "Don is the Cossack region!", and its historical past is invariably viewed through the prism of Cossack history. Don Cossacks can be designated as an ethno-cultural brand of the Rostov region, besides - the basis, symbolizing the region as a whole. Speaking about the hierarchy of ethnographic brands in the context of development, the second can be called a group of Don Armenians, which is the core of the modern Armenian population of the Rostov region. One can name Rostov-on-Don and Taganrog as the ethno-cultural brands that symbolize the Rostov region. This does not mean rejection from positioning in sociocultural and educational practices of other groups of people who have original cultures, often displaying a high level of self-awareness and, as a consequence, ethnic demands. Here one should take into account the smaller number, the later appearance on the Don and the more limited material and artifactual component of their cultures in the general cultural potential of the region. Considering the growth of ethnic self-awareness, the dynamics of interethnic communications, as well as the socio-cultural activity of different ethnic communities, it is possible to admit not only changes in the semantics of existing symbols, but also the formation of new ethno-cultural brands. 


\section{Лumepamypa}

1. Авдулов Н.А. Векторы этнокультурных процессов на Юге России // Энциклопедия культур народов Юга России. Ростов-на-Дону, 2005. Т. 1.

2. Белозеров В. Этническая карта Северного Кавказа. М., 2005.

3. История казачества Дона и Северного Кавказа. Ростов-на-Дону: Изд. Ростовского госуниверситета, 2003.

4. Казаров С.С., Тикиджьян Р.Г. Армяне // Народы Юга России. Энциклопедический словарь / Под ред. А.А. Озерова. Ростов н/Д, 2016.

5. Копылов В.П. Греки древние // Энциклопедия культур народов Юга России: В 9 т. Т.1.Народы Юга России. Ростов-на-Дону, 2005.

6. Ларенок П.А. Итальянцы (венецианцы, генуэзцы, пизанцы и др.) // Энциклопедия культур народов Юга России: В 9 т. Т.1. Народы Юга России. Ростов-на-Дону, 2005.

7. Палеев Ю.Н. Северный Кавказ // Регионоведение (Юг России: краткий тематический словарь. Ростов-на-Дону, 2003.

8. Пронштейн А.П. Земля Донская в XVIII веке. Ростов-на-Дону., 1964.

9. Российский Кавказ. Книга для политиков / Под ред. В.А. Тишкова. М., 2007.

10. Черницын С.В. Украинцы // Народы Юга России. Энциклопедический словарь / Под. Ред. А.А. Озерова. Ростов-на-Дону, 2016.

11.Черных Е.Н. Евразийский «степной пояс»: у истоков формировании // Природа. 2008. № 3.

12.Шелов Д.Б. Танаис и Нижний Дон в ІІІ-І вв. д.н.э. М., 1970.

13.Шелов Д.Б. Танаис и Нижний Дон в первые века нашей эры. М., 1972.

14.Шишова Н.В. Провинциальная культура как социоисторический френомен // Вестник ДГТУ. Сер. Проблемы гуманитарных и естественных наук. Ростов-наДону, 2003.

15.Шовунов К.П. Калмыки в составе российского казачества. Элиста: Союз казаков Калмыкии, Калмыцкий институт общественных наук, 1992.

16.Шпагин С.А. Область Войска Донского 100 лет назад. К итогам Первой Всеобщей переписи населения Российской империи 1897 г. // Донской временник (краеведческий альманах). Ростов-на-Дону, 1997.

\section{References}

1. Avdulov N.A. Vectors of ethnocultural processes in the South of Russia // Cultures encyclopedia of the South Russia people. Rostov-on-Don, 2005. V. 1.

2. Belozerov V. Ethnical map of the North Caucasus. M., 2005.

3. Cossacks History of the Don and the North Caucasus. Rostov-on-Don, 2003.

4. Kazarov S.S., Tikidzhyan R.G. The Armenians // People of the south of Russia. Encyclopedic dictionary / Ed. A.A. Ozerov. Rostov-on-Don, 2016.

5. Kopylov V.P. Ancient Greeks // Encyclopedia of Cultures of South Russia people: In 9 v. V.1.South Russia people. Rostov-on-Don, 2005.

6. Larenok P.A. The Italians (Venetians, Genoeses, Pisans and etc. // Cultures Encyclopedia of the South Russia People: In 9 v. V.1.South Russia people. Rostov-onDon, 2005.

7. Paleev Yu.N. The North Caucasus // Regional studies (The south of Russia: the brief idioglossary. Rostov-on-Don, 2003.

8. Pronshtein A.P. The Don land in the XIII century. Rostov-on-Don, 1964. 
9. The Russian Caucasus. The book for politicians / Ed. V.A. Tishkov. M., 2007.

10. Chernitsyn S.V. Ukrainians // People of the South of Russia. Encyclopedic Dictionary / Ed. A.A. Ozerov. Rostov-on-Don, 2016.

11. Chernykh E.N. Eurasian "steppe belt": at the origins of formation // Nature. 2008. No 3.

12. Shelov D.B. Tanais and the Lower Don in the III-I centuries. BC. M., 1970.

13. Shelov D.B. Tanais and the Lower Don in the first centuries of our era. M., 1972.

14. Shishova N.V. Provincial culture as a sociohistorical phenomenon // Vestnik of DSTU. The problems of humanitarian and natural sciences. Rostov-on-Don, 2003.

15. Shovunov K.P. Kalmyks in the Russian Cossacks composition. Elista, 1992.

16. Shpagin S.A. The area of the Don Army 100 years ago. To the results of the First General Census of the Russian Empire of 1897 // Don time (the regional almanac). Rostov-on-Don, 1997. 